\title{
D-30 SEDIMENTARY CHARACTERS CHANGES IN FRACTURED MICRITIC RESERVOIRS - EXAMPLE OF THE ABIOD-BOU DABBOUS FORMATIONS IN NORTHERN TUNISIA
}

M.H. NEGRA', B. MARDASSI ${ }^{2}$ and S. MELKI ${ }^{2}$

'Bizerte Faculté des Sciences, Dép. Sciences de la Terre, Lab. Sédiments, Environnements et Ressources Naturelles, 7000 Bizerte, Tunisia

2 Tunis Faculté des Sciences

Fractured micritic reservoir rocks constitute in Tunisia additional hydrocarbon targets since the discovery of oil in some fields such as in Sidi el Kilani, Zinia, Belli, (Ben Ferjani et al. 1990) El Menzah etc.. In Tunisia, the main developed fractured micritic carbonates are constituted of the Campanian Abiod Formation (Burollet, 1956 ; Negra et al, 1994 ; Negra, 1998) and the Ypresian Bou Dabbous Formation (Fournié, 1978 ; Loocks et al, 1996). At a first glance, these fine-grained carbonatic formations, appear monotonous in terms of facies organisation. However, detailed sedimentological studies show that these two micritic reservoirs exhibit vertical and lateral rapid variations in terms of thickness and sedimentary characters. The Jebel El Ghorfa and Jebel El Mekki outcrops, located in the Grombalia area (Northern Tunisia), show that these sedimentary variations could appear on a short distance (about $1 \mathrm{~km}$; Negra \& Mardassi, 2000).

The Abiod Formation which is commonly constituted of well bedded micritic limestones, shows in the studied sector rapid lateral variations in thickness and facies. In fact, from South to North of Jebel El Ghorfa, the Abiod Formation thickness changes from 2 to $30 \mathrm{~m}$. In parallel, structures, textures, composition, diagenetic features and porosity nature clearly change. In Jebel el Ghorfa South (Sidi Rhilane), the Abiod Formation which unconformably overlies Aptian shales (Turki, 1988 ; Ouahchi et al., 1993), is represented by thin massively bedded limestones highly bioturbated and topped by a bored hard ground probably corresponding to an emergence surface. Limestones consist of packstones rich in planktonic foraminifera associated to benthonic foraminifera, quartz grains, phosphatic and glauconitic grains and scarce bioclastic debris.

Diagenetic features mainly represented by solution, early cementation and local dolomitisation. Solution processes are responsible of the creation of intragranular pores, especially within some Globotruncana chambers. Early cementation processes are responsible of a hard ground genesis on Abiod Formation top. Toward the North, massive facies progressively change to well bedded and fractured limestones which are locally separated by thin marly intercalations. Diagenetic features, affecting the planktonic foraminifera rich wackestones-packstones, mainly consist of compaction features and intraparticular cementation processes. To the South of Jebel El Ghorfa, in Jebel El Mekki, the Abiod Formation fossilises slump marks suggesting its deposition on a sloping profile globally dipping to the South-East.

SEM analyses show that micrites constituting the Abiod Formation are basically formed of nanofossils mainly represented by coccoliths and their debris. However, from South to North, coccoliths appear more frequent and relatively well preserved. Micrites diagenesis is mainly expressed by spar crystals constituting an intergranular cement (M'Rabet et al. 1996 ; Negra et al. 1994). 
The Bou Dabbous Formation (Fournié, 1978) shows in the Jebel El Ghorfa sector similar thickness and facies variations to those described in the Abiod Formation. In fact, to the South, in Sidi Rhilane, the Bou Dabbous Formation (only $1 \mathrm{~m}$ in thickness) which clearly ravinates the upper part of the underlying El Haria shales, is formed of massively bedded limestones. The latter consist of grained bioclastic packstones rich in Globigerinids associated to frequent phosphatic and glauconitic grains. To the North, the Bou Dabbous Formation which progressively gets thicker, reaching $65 \mathrm{~m}$, exhibits vertical and lateral facies changes (Mardassi, 1998). In fact, according to textures and composition changes, three units have been identified. From base to top, the unit I $(20 \mathrm{~m})$ is associating, in similar proportions, Globigerinids and Radiolarians (De Wever et al. 1994) ; the unit II (30m) is rather rich in Globigerinids ( $80 \%$ of components) ; the unit III (about $15 \mathrm{~m})$ is basically constituted of Radiolarians forming $80 \%$ of the limestone components. Laterally, from North to South, the Radiolarian-rich unit III is onlapping the Globigerinid-rich unit II which is onlapping the unit $I$ that is associating Globigerinids and Radiolarians and forming the whole Bou Dabbous Formation in Sidi Rhilane area.

SEM analyses show that the Bou Dabbous micrites are mainly constituted of nanofossils essentially represented by coccoliths associated to anhedral to subhedral micritic grains and microspar crystals. However, coccoliths are frequent and relatively well preserved to the North, particularly within units II and III.

Concerning diagenesis, diagenetic features affecting limestones change from south to North. Within the relatively elevated area, developed to the South (Sidi Rhilane area), diagenetic modifications mainly consist of solution and early cementation. The latter appear to preferentially affect the grained limestones rich in phosphatic grains which initially could be relatively permeable. Solution features are creating intraparticular pores in foraminifera chambers. Cementation which is basically intraparticular, starts to occur since an early stage, as suggested by a geopetal infilling of some cavities by a micritic sediment. Cementation is mainly insured by microsparitic to sparitic crystals mainly developed in foraminifera chambers, especially to the North. A dolomitic cement was identified in the Southern part, preferentially infilling microfractures. Silicification processes preferentially occur in the Northern part, espacially within the lower part of the Bou Dabbous Formation. Silica that could be remobilised from initially siliceous Radiolarians and Sponges, is mainly expressed by chalcedony crystals affecting some bioclasts.

On the whole, the lateral variations in thickness and lateral changes both appear within the Abiod and Bou Dabbous Formations. The most elevated area occupying the Southern part of Jebel El Ghorfa (Sidi Rhilane area) appears acting as a high since the end of the Aptian period. Despite the Campanian transgression expressed by the Abiod micritic limestones deposition, this area has continued to form a high during the Late Cretaceous and the Lower Eocene, as suggested by an emergence surface on top of the Abiod Formation. From the Sidi Rhilane area toward both sides (North and South) the deepening could be related to an Aptian to post-Aptian structuration responsible of an irregular topography. The latter could be, in addition, affected by a distensive faulting, Upper Cretaceous in age, at least favouring and facilitating facies deepening from Sidi Rhilane.

In terms of reservoir potential, despite certain diagenetic modifications locally enhancing porosity and permeability of limestones, fractures appear to be the most potential pores. The latter which are at least partly open, insure the interconnection of all types of pores.

The discovery of hydrocarbon in the Abiod Formation (in Zinia field) and in the Bou Dabbous Formation (in Belli and El Menzah fields) near the studied outcrops (about $15 \mathrm{~km}$ to the East), 
confirm the possibilities of these micritic Formations in terms of fractured reservoir rocks and consequently of interesting potential targets.

\section{REFERENCES}

BEN FERJANI A., BUROLLET P.F. \& MEJRI F. (1990) Petroleum Geology of Tunisia. ETAP, Tunis, 194p.

BUROLLET P.F. (1956) Contribution à l'étude stratigraphique de la Tunisie centrale. Ann. Mines Géol., Tunis, $\mathrm{n}^{\circ} 18,345 \mathrm{p}$.

DE WEVER P., AZEMA J. \& FOURCADE E. (1994) Radiolaires et radiolarites : production primaire, diagenèse et paléogéographie. Bull. Centres Rech. Explor.-Prod. elf aquitaine, France, vol.18, 1, pp. $1-379$.

FOURNIE D. (1978) Nomenclature lithostratigraphique des séries du crétacé supérieur au Tertiaire de Tunisie ; Bull. Cent. Rech. Explo. Prod. Elf Aquitaine, Vol. 2, nº 1, pp. 97-148.

LOOCKS R. G., MOODY R. T., BELLIS J. \& BROWN A. A. (1996) Regional depositional setting and pore network of the El Garia Formation. (Metlaoui group, Lower Eocene), Offshore Tunisia. Proceedings of the $5^{\text {th }}$ Tunisian Petroleum Exploration Conference. Mem. $\mathrm{N}^{\circ} 10$, ETAP, Tunis, pp. 147-172.

MARDASSI B. (1998) Les faciès micritiques producteurs d'hydrocarbures dans l'Ypresien de la région de Grombalia; Caractères sédimentaires, Diagenèse et Aspect réservoir. Mém. D.E.A, Fac. Sc. Tunis, 87p.

M'RABET A., NEGRA M.H., PURSER B.H., SASSI S. \& BEN AYED N. (1986) Micrite diagenesis in Senonian rudist buildups in central Tunisia. In : PURSER B.H. \& SCHROEDER J.H., Eds., Reef Diagenesis. Springer, vol. special., pp. 210-223.

NEGRA M.H., PURSER B.H. and M'RABET A. (1994) Permeability and Porosity evolution in dolomitized Upper Cretaceous pelagic limestones of Central Tunisia. Spec. Publs Int. Ass Sediment, 21, pp. 309-323.

NEGRA M.H. (1998) Origins of changes in Abiod Formation Potential Properties. Proceedings of the $6^{\text {th }}$ Tunisian Petroleum Exploration Conference. Mem. N $^{\circ} 12$, ETAP, Tunis, pp. 251-266.

NEGRA M.H. \& MARDASSI B. (2000) Sedimentological characters of the Bou Dabbous Formation in the Grombalia area outcrops. The $7^{\text {th }}$ Tunisian Petroleum Exploration \& Production Conference - Tunis, ETAP, Abst. Vol. pp. 75-76.

NEGRA M.H. \& MARDASSI B. (2000) The Bou Dabbous Formation in the Grombalia area outcrops. Sedimentological characters and diagenesis. Proceedings of the $7^{\text {th }}$ Tunisian Petroleum Exploration Conference. Mem. $\mathrm{N}^{\circ} 14$, ETAP, Tunis. (to appear).

OUAHCHI A, BISMUTH H. et TURKI M.M. (1993) Nouvelles données sur le Crétacé et l'Eocène des environs de Grombalia. Géologie Méditerranéenne, tome XX n ${ }^{\circ}$, pp. 25-43.

TURKI M.M. (1988) Polycinématique et contrôle sédimentaire associé sur la cicatrice ZaghouanNebhana. Revue des Sciences de la terre, vol. 7, 252p. 

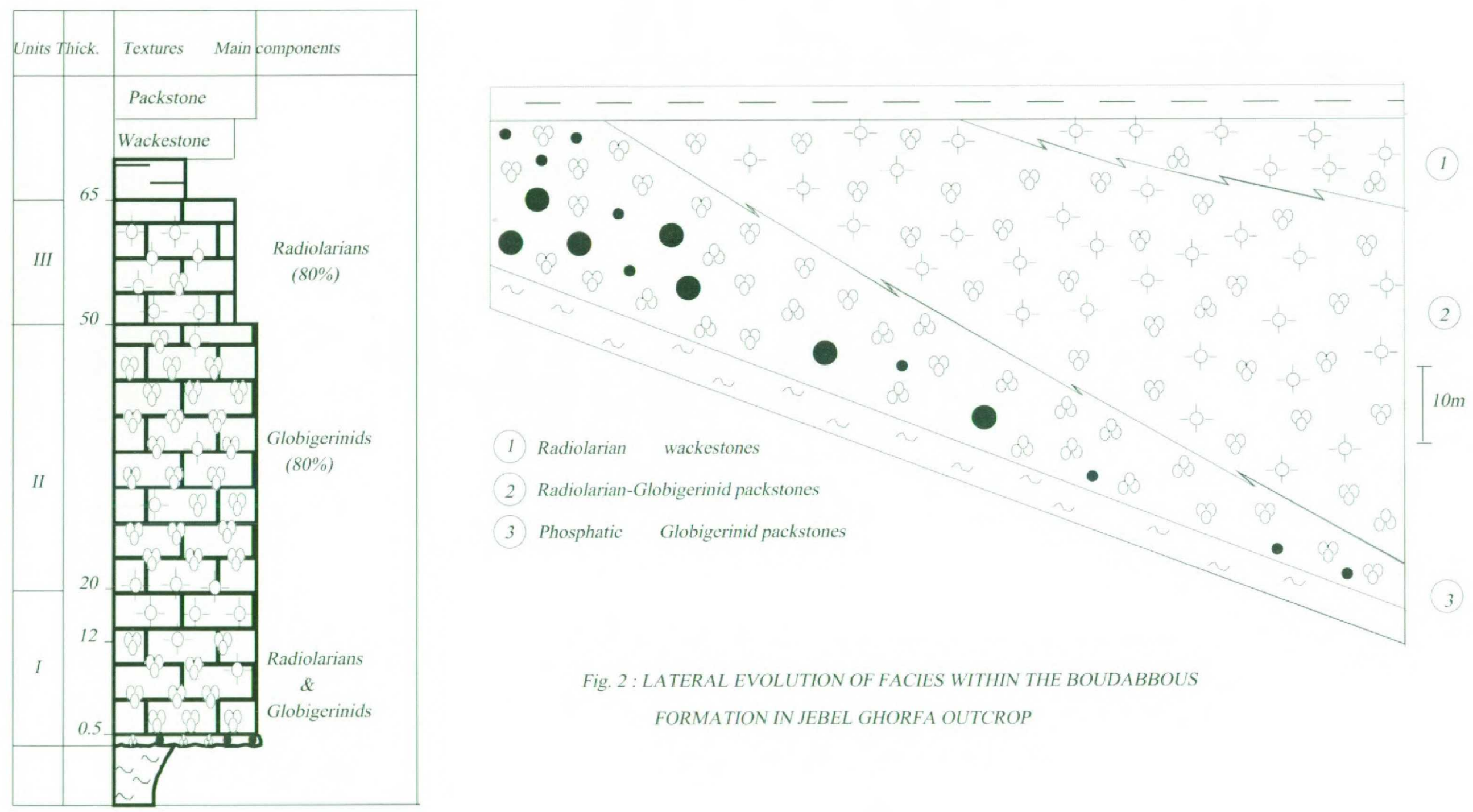

Fig. 2 : LATERAL EVOLUTION OF FACIES WITHIN THE BOUDABBOUS FORMATION IN JEBEL GHORFA OUTCROP

FII. 1: VERTICAL EVOLUTION OF BOU DABBOUS FACIES INA SYNTHETHICAL SECTION 